\title{
Study Literature of Extraction Lipid Method from Microalgae Nannochloropsis sp
}

\author{
Adelya Kristia Putri ${ }^{1}$, Tanti Irma Nuraini ${ }^{2}$, Yustia Wulandari Mirzayanti ${ }^{3 *}$
}

\begin{abstract}
Biodiesel is a promising alternative fuel obtained from plant oils and animal fats through the esterification process with alcohol. Lipid microalgae Nannochloropsis sp. can be used as raw material for the production of biodiesel or biofuel with oil content in the microalgae Nannochloropsis sp. as much as $21.3-32.7 \%$ so, it has the potential to be used as a raw material in making biodiesel. Biodiesel produced from microalgae biomass is the most suitable alternative fuel for the future and environmentally friendly fuel. In microalgae lipid extraction, Nannnochloropsis sp. using several process aids such as autoclave, microwave, and soxhlet. Different types of solvents are used to determine the\% yield of lipids present in microalgae. Extraction was carried out to compare the extraction method using autoclave, microwave, and soxhlet to obtain the best method that produced the most substantial \% lipid. An autoclave obtained the most abundant lipid yield with n-hexane solvent with a ratio of 3: 1 solvent and algal oil. Thus, this review describes the lipid extraction of the microalgae Nannochloropsis sp. with various extraction aids and different solvent types related to lipid production over the past few years.
\end{abstract}

Keywords_Extraction, Lipid, Nannochloropsis sp, Microalgae, Solvent

\section{INTRODUCTION}

A lternative energy at this time is needed to meet the needs as a substitute for petroleum. Besides, alternative energy used is also known to be more environmentally friendly, so it does not cause damage to to.nature. One of the alternative energies which are used at this time is the biofuel Fatty Acid Methyl Ester (FAME).

Biofuel FAME or commonly known as biodiesel which can be defined as diesel fuel made from biological materials composed of methyl or ethyl esters, which are obtained by reacting triglycerides and alcohol and have characteristics like diesel oil [1]. The manufacture of biodiesel from vegetable oils such as algal oil has received a lot of attention. Algae is a good source of biodiesel which can produce 200 times more oil than other vegetable oils such as palm oil, peanut oil, and soybean oil [2].

Microalgae is one of the potential natural sources in making biodiesel because it contains high oil content. Microalgae is the fastest organisms in photosynthesis, so It has high productivity. Types of microalgae that have a high enough oil content include Isochrysis galbana: $21.8-38.4 \%$, Gymnodinium sp 18.3-22.6\%, Nannochloropsis.sp 21.3$32.7 \%$, Tetraselmis sp. 10.6-10.1\%, and Rhodomonas sp. 9.5-12.5\%. Isochrysis galbana has the most oil content, but based on an easily available source, Nannochloropsis sp. becomes an option to become a FAME biofuel [3].

The advantages of microalgae as raw material for making biodiesel are because they are easy to develop, genetically engineered, have a short harvest period, and contain useful biomass such as carbohydrates, protein, or fat. The content

\footnotetext{
${ }^{1}$ Adelya Kristia Putri, Department of Chemical Engineering, Institut Teknologi Adhi Tama Surabaya, Surabaya, 60117, Indonesia.

${ }^{2}$ Tanti Irma Nuraini, Department of Chemical Engineering, Institut Teknologi Adhi Tama Surabaya, Surabaya, 60117, Indonesia.

${ }^{3}$ Yustia Wulandari Mirzayanti, Department of Chemical Engineering, Institut Teknologi Adhi Tama Surabaya, Surabaya, 60117, Indonesia. Email: yustiawulandari_che@itats.ac.id
}

of microalgae is dominated by fat as a raw material for biodiesel [4].

The microalgae breeding process only takes ten days to be ready to harvest so that mathematically the productivity reaches $(120,000 \mathrm{~kg}$ biodiesel / $\mathrm{Ha}$ year) more than 20 times the productivity of palm oil $(5,800 \mathrm{~kg}$ biodiesel / Ha year) and 80 times that of castor oil $(1,500 \mathrm{~kg}) /$ biodiesel / Ha year) [4].

Nannochloropsis sp. is one of the types of microalgae that produce the main product lipids. In Indonesia, the utilization of microalgae species is only limited to feed livestock fish and shrimp. Lipid content of Nannochloropsis sp. ranged from $31-68 \%$ of the dry weight. This lipid is compound base-forming material fuel. The extraction of lipids can be done by extraction using nonpolar solvents, considering that lipids are nonpolar compounds that dissolve in nonpolar solvents [5].

A literature study on the method of microalgae fat extraction for Nannochloropsis sp. such as solvent extraction, enzymes, $\mathrm{CO}_{2}$ extraction, ultrasonic extraction, microwave extraction, etc. have been reviewed. The results of previous studies on variations in extraction methods focused on studying the ratio of $\%$ of lipid yields based on the type of solvent used in each method. The type of solvent significantly affects the \% yield of lipids obtained through various extraction methods. Therefore, a literature study on the method of lipid extraction process from microalgae Nannochloropsis sp. it's worth doing.

\section{METHOD}

\section{A. Microwave Extraction Process}

According to H. Hindarso et al. [2], the following is an explanation of Figure 1. Extraction of dry microalgae Nannochloropsis sp. was carried out using n-hexane as solvent at the ratio solvent to dry algae 4: 1 (v:w). Extraction run at a temperature of $65^{\circ} \mathrm{C}$ for 5 hours. Stopping of extraction processes if it has reached the specified time limit. The extracted lipids were separated 
from the solvent by rotavapor distillation to purify the microalgae oils.

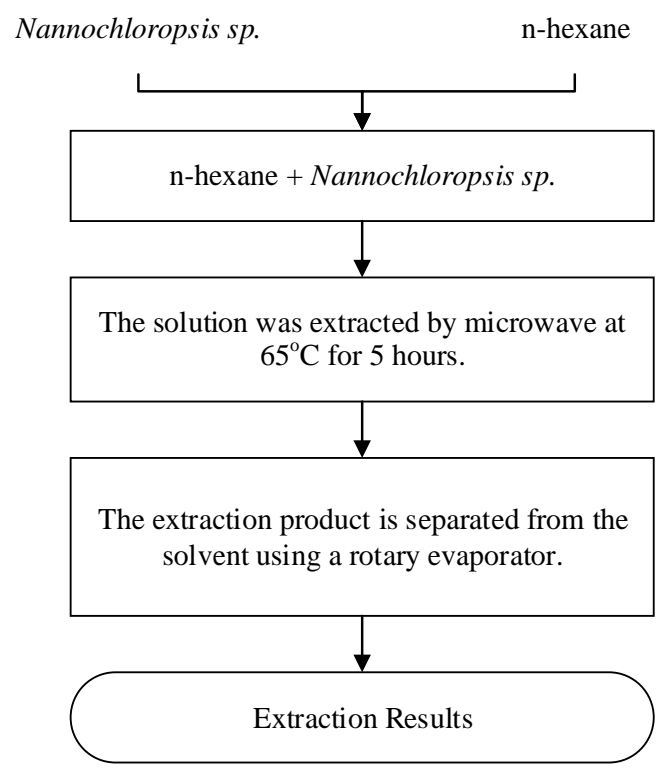

Figure 1. Diagram of Extraction Method Using Microwave [2]

\section{B. Extraction Process with the Autoclave Method}

According to A. Purwanti, et al [6], the following was an explanation of Figure 2. Prepare raw materials in the form of dried Nannochloropsis sp microalgae and methanol as solvent. Dissolve the algae into methanol then extract the solution using an autoclave with a pressure variation between 25 psi to 75 psi for 30 minutes to 120 minutes. Next, screeming process was carried out by filtering the mixture to obtain a lipid mixture and solvent to be separated from solid. Separating process was continued by distillation to separate lipids from solvent methanol. The lipid obtained from the distillation was processed to determine the amount of lipid removed.

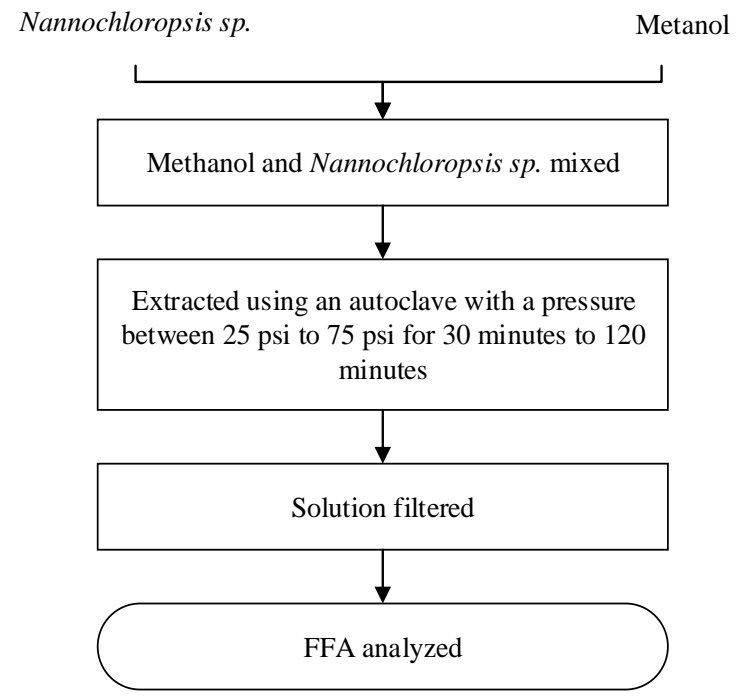

Figure 2. Diagram of Extraction Method Using Autoclave [7]

\section{Extraction Process with the Soxhlet Method}

According to R. Behling, et al. [7], the following was an explanation of Figure 3. The researchers prepared raw materials in the form of dried Nannochloropsis sp microalgae and hexane, ethyl lactate, ethyl acetate, CPME (Cyclopentyl methyl ether), and 2-MeTHF (2-methyl tetrahydrofuran). Then, we mixed dry microalgae with a solvent with ratio 1: 100 of biomass to solvent, and then, it extracted the solution with soxhlet for 8 hours as per ISO 659. The system works under reflux, where the solvent evaporates and condenses back into the thimble while extracting lipids from the biomass. The system was rinsed for 20 minutes, and the solvent was evaporated for about 30 minutes. Afterward, the result of the extraction dried in an oven at $60^{\circ} \mathrm{C}$ for 3 hours and placed the extraction results on the desiccator during the night and then analyzing FFA.

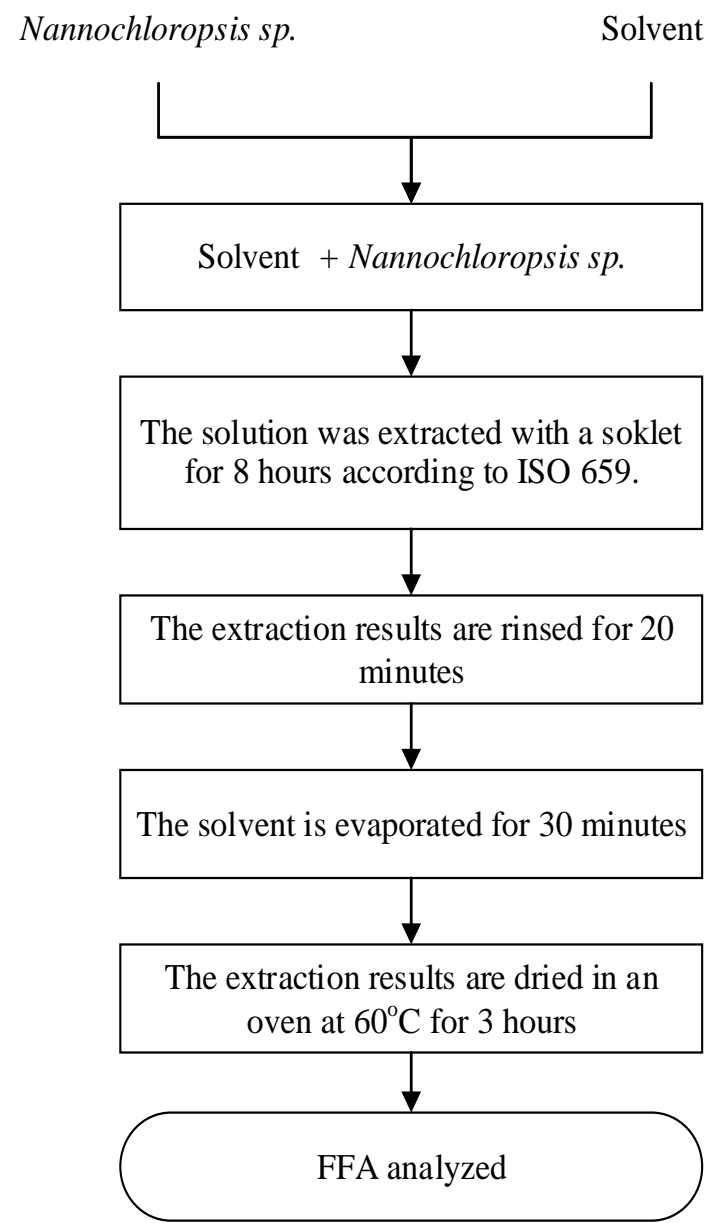

Figure 3. Diagram of Extraction Method Using Soxhlet [8] 


\section{RESULTS AND DISCUSSION}

Based on literature studies from previous studies, it was found that the $\%$ of lipids from microalgae Nannochloropsis sp. with various extraction methods such as Soxhlet, microwave, and autoclave can be seen in Table 1.

Extraction, in general, is a process of separating the active substance from a solid or a liquid by using solvents [8]. Parameters such as the ratio of biomass to solvent, temperature, and time spent during the extraction process also affect the yield of oil obtained [3]. Along with the efforts to make biodiesel production costs effective and energy efficient, an important consideration is to make sure that all the operations, materials, and techniques involved are environmental-friendly [9]. Finding the most efficient method and optimized conditions for the extraction of lipids were important for reducing the cost of biodiesel production from microalgae [10]. Based on literature studies, it was found the advantages and disadvantages of several existing extraction methods $[12,13]$.

TABLE 1.

DATA FROM THE STUDY OF LITERATURE EXTRACTION PROCESS

\begin{tabular}{|c|c|c|c|c|c|}
\hline Extraction & Solvent & Ratio & Operation Condition & $\%$ lipid & Researcher \\
\hline \multirow{2}{*}{ Soxhlet } & n-hexane & $20: 1$ & At $80^{\circ} \mathrm{C}$ for 3 hours & $\begin{array}{c}0.364 \mathrm{~g} \\
\text { oil/dry algae }\end{array}$ & [9] \\
\hline & Ethyl Lactate & $100: 1$ & $\begin{array}{c}\text { Extraction for } 8 \text { hours according } \\
\text { to ISO } 659\end{array}$ & $31.1 \%$ & [8] \\
\hline \multirow{3}{*}{ Microwave } & \multirow[b]{2}{*}{ n-hexane } & $4: 1$ & At $65^{\circ} \mathrm{C}$ for 5 hours & $77.16 \%$ & [2] \\
\hline & & $1: 1$ & $\begin{array}{l}\text { At } 75^{\circ} \mathrm{C} \text { for } 10 \text { minutes with } 2450 \\
\text { MHz wavelength }\end{array}$ & $\begin{array}{l}145.11 \mathrm{gr} / 50 \\
\mathrm{lt}\end{array}$ & [10] \\
\hline & $\mathrm{NaCl}$ & $2: 1$ & At $100^{\circ} \mathrm{C}$ for 30 minutes & $16.1 \%$ & {$[11]$} \\
\hline \multirow{2}{*}{ Autoclave } & Methanol & $10: 1$ & Pressure at 45 psi for 120 minutes & $31.02 \%$ & [7] \\
\hline & Hexane & $3: 1$ & At $140^{\circ} \mathrm{C}$ for 4 hours & $78.8 \%$ & {$[11]$} \\
\hline
\end{tabular}

TABLE 2 .

LIPID CONTENT MEASUREMENT BY THE BLIGH \& DRYER METHOD WITH VARIOUS PRETREATMENTS ACCORDING M. H. KWON ET AL. [13]

\begin{tabular}{|c|c|c|}
\hline No & Measurement method & Lipid content (\%) \\
\hline 1. & Bligh \& Dryer method + (BDM) & $13.4 \%$ \\
\hline 2. & Autoclave + BDM & $13.9 \%$ \\
\hline 3. & Microwave + BDM & $14.3 \%$ \\
\hline 4. & Ultrasonication + BDM & $16 \%$ \\
\hline 5. & Bead Beater + BDM & $16.1 \%$ \\
\hline
\end{tabular}

According to research that has been done by M. H. Kwon et al. [13] in Table 2, BDM was mostly a solvent extraction process, which is influenced by factors such as the type of organic solvent, temperature, and cell wall rigidity. M. H. Kwon et al. [13] also improved the efficiency of BDM by employing pre-treatment processes such as bead-beating, ultrasonication, microwaving, or autoclaving to enhance solvent extraction of the lipids from the microalgae. Each of these pre-treatments has also been used as a mechanical technique to extract lipids from microalgae. Based on Table 2, pre-treatment using a bead beater process and lipid measurement using conventional Bligh \& Dryer were the best process that produces the most lipids, with the result of $\%$ lipid is $16.1 \%$. This process was better than the pretreatment with the ultrasonic and lipid measurement by conventional Bligh \& Dryer with lipid content of $16 \%$. Still, in Table 1, the best lipid and biofuel yield results were obtained using an autoclave with hexane as solvent.
The following were some of the extraction methods and lipid content resulting from Table 1.

It can be seen in Figure 4 that the extraction method using the autoclave was the method that produces the most $\%$ lipids of $78.8 \%$ with hexane solvents. According to $\mathrm{C}$. $\mathrm{Wu}$ et al. [14], a mixture of solvents from polar and nonpolar organic solvents caused higher lipid yield compared to only nonpolar solvents. The highest lipid yield was obtained by using a combination of chloroform, and methanol is $94.9 \%$. It is worth noting that the lipid yields from hexane and petroleum ether extraction were much lower than using chloroform, with the result is $26.3 \%$. However, they were all classified as nonpolar solvents, which was consistent with their polarity in research C. Wu et al. [15] found that the addition of surfactants and hexane improved algal lipid yield, compared to solvent extraction.

Extraction research conducted M. Musdalifah et al. [11] produced 145.11 grams in 50 liters of media with MAE 
(Microwave-Assisted Extraction) to optimize the process of breaking down the cell wall to make it easier for oil to get out of the cell and dissolve with n-hexane solvent. The operating conditions at extraction are temperature $75^{\circ} \mathrm{C}$ for 10 minutes and wavelength of $2450 \mathrm{MHz}$. While on research Y. S Pradana et al. [8] produced a lipid of $0.0346 \mathrm{~g}$ of oil/gr dry algae, which was the highest lipid yield compared to other microalgae after extracting with soxhlet and n-hexane solvent for 3 hours at a temperature of $80^{\circ} \mathrm{C}$.
Different results were shown in Figure 5 [8]. According to the authors, all bio-based solvents outperformed the hexane extraction capacity, with 2-MeTHF and ethyl lactate, each giving double and triple lipid extraction results compared to conventional solvents, hexane. The lowest \% lipid obtained in the extraction process was from hexane solvents, with a $\%$ lipid of $9.4 \%$. At the same time, the highest lipid\% was obtained by ethyl lactate solvent of $31.1 \%$.

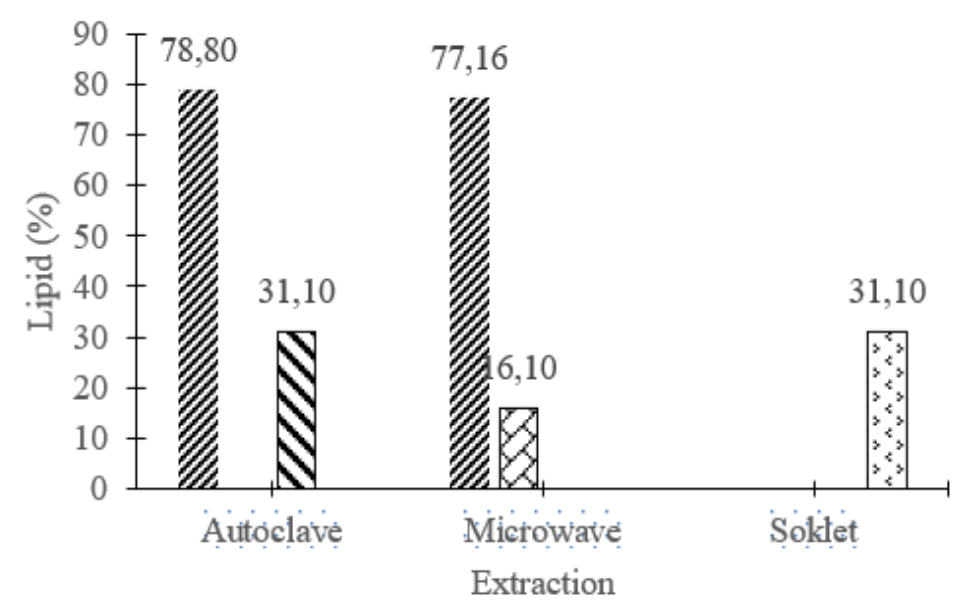

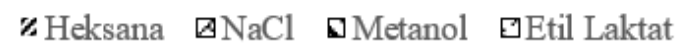

Figure 4. Effect of Extraction Methods on the Results of \%Lipid by Various Solvent

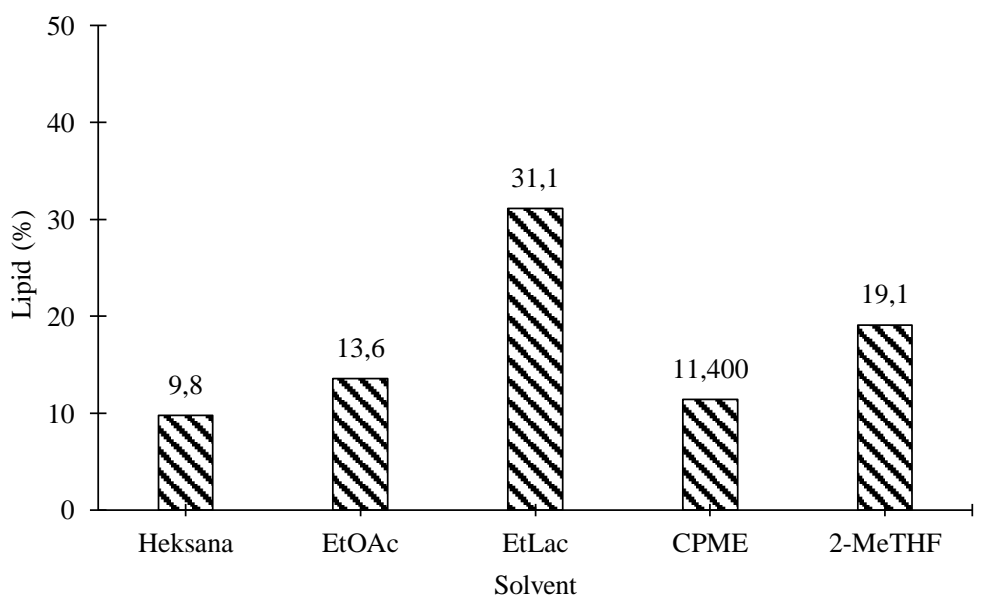

Figure 5. Effect of Solvent on \%Lipid [8]

According to Zghaibi et al. [12], The B\&D method was an established and rapid method for lipid extraction, while soxhlet is a commonly used method for most extraction due to its high solvents acceptability depending on the product of interest. The result of lipid extraction for both conventional methods indicated that the $\mathrm{B} \& \mathrm{D}$ method extracted four times more lipids at $18 \%$, in comparison to only $4.5 \%$ extracted with the soxhlet method. Despite the lengthy extraction process, the soxhlet method failed to give a better extraction yield. The concentration of the solvent also affects the extraction yield, Zghaibi et al. [12] stated that lipid results increase and result with an increase in the concentration of $\mathrm{NaCl}$ concentration up to $10 \%$, with $6.88 \%$ exerting the highest yield, but, in yield, the reduction was increasing salt concentration.

\section{CONCLUSION}

In this review, the result of higher lipids was compared by several methods. Results lipids produced mostly large depending on the methods and solvents are used. The extraction method using autoclave with solvent hexane (3:1) could produce the most abundant lipid content, with the resulting \% lipid is $78.8 \%$. Further literature studies are needed to determine a suitable extraction 
method, not only from the effect of the solvent but also from the influence of the molar ratio, the operating conditions to obtain the maximum\% lipid.

\section{REFERENCES}

[1] Y. T. Rahkadima, "Produksi Biodiesel Dari Dedak Padi Menggunakan Metode In Situ Dengan Bantuan Microwave”, pp. 4, 2017.

[2] H. Hindarso, A. Aylianawati, and M. Edy Sianto, "Biodiesel Production from the Microalgae Nannochloropsis by Microwave Using $\mathrm{CaO}$ and $\mathrm{MgO}$ Catalysts", Int. J. Renew. Energy Dev., vol. 4, no. 1, pp. 72-76, Feb 2015.

[3] S. Deshmukh, R. Kumar, and K. Bala, "Microalgae biodiesel: A review on oil extraction, fatty acid composition, properties and effect on engine performance and emissions," Fuel Process. Technol., vol. 191, pp. 232-247, Agustus 2019.

[4] B. Wijanarko, "Ekstraksi Lipid Dari Mikroalga (Nanochloropsis Sp.) Dengan Solven Methanol Dan Chloroform," vol. 1, no. 1, pp. 9, 2012.

[5] Y. Chisti, "Biodiesel from microalgae", Biotechnol. Adv., vol. 25, no. 3, pp. 294-306, Mei 2007.

[6] A. Purwanti, "Pengaruh Proses Ekstraksi Bertekanan Dalam Pengambilan Lipid Dari Mikroalga Jenis Nannochloropsis Sp. Dengan Pelarut Metanol," vol. 7, no. 2, pp. 6, 2015.

[7] R. Behling, S. Valange, dan G. Chatel, "Heterogeneous catalytic oxidation for lignin valorization into valuable chemicals: what results? What limitations? What trends?", Green Chem., vol. 18, no. 7, pp. 1839-1854, 2016.

[8] Y. S. Pradana, H. Sudibyo, E. A. Suyono, Indarto, and A. Budiman, "Oil Algae Extraction of Selected Microalgae Species Grown in Monoculture and Mixed Cultures for Biodiesel Production," Energy Procedia, vol. 105, pp. 277-282, Mei 2017.

[9] H. Sati, M. Mitra, S. Mishra, and P. Baredar, "Microalgal lipid extraction strategies for biodiesel production: A review," Algal Res., vol. 38, pp. 101413, Mar 2019.

[10] M. Mubarak, A. Shaija, and T. V. Suchithra, "Ultrasonication: An effective pre-treatment method for extracting lipid from Salvinia molesta for biodiesel production," Resour.-Effic. Technol., vol. 2, no. 3, pp. 126-132, Sep 2016.

[11] M. Musdalifah, Y. Rustam, and S. Amini, "Kultivasi Dan Ekstraksi Minyak Dari Mikroalga Botryococcus Braunii Dan Nannochloropsis Sp.," BIOMA, vol. 11, no. 2, pp. 98, Okt 2015.

[12] Zghaibi, Omar, Kamal, Biak, and Harun, "Microwave-Assisted Brine Extraction for Enhancement of the Quantity and Quality of Lipid Production from Microalgae Nannochloropsis sp.," Molecules, vol. 24, no. 19, pp. 3581, Okt 2019.

[13] M. H. Kwon, and S.H. Yeom. 2015. "Optimization of One-Step Extraction and Transesterification Process for Biodiesel Production from the Marine Microalga Nannochloropsis Sp. KMMCC 290 Cultivated in a Raceway Pond." Biotechnology and Bioprocess Engineering 20(2):276-83.

[14] C. Wu, Y. Xiao, W. Lin, J. Zhu, H. De la Hoz Siegler, M. Zong, J. Rong, "Surfactants assist in lipid extraction from wet Nannochloropsis sp," Bioresour. Technol., vol. 243, pp. 793-799, Nov 2017. 